\title{
バルク金属ガラス粉のホットプレス固化メカニズム
}

\author{
渡辺 龍三的 1 , 木村 久道的 2 , 加藤 秀美的 2 , 井上 明久祙 \\ 的1 青森職業能力開発短期大学校, $=037-0002$ 五所川原市飯詰字狐野 171-2. \\ 42 東北大学金属材料研究所, T 980-8577 仙台市青葉区片平 2-1-1. \\ 出 3 東北大学総長, $=980-8577$ 仙台市青葉区片平 2-1-1.
}

\section{Hot Pressing Consolidation Mechanisms of Bulk Metallic Glass Powders}

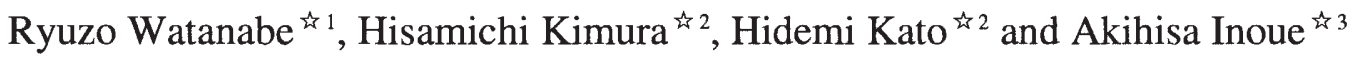 \\ \&1 Tohoku Polytechnic College, Aomori, 171-2 Goshogawara, Aomori 037-0002, Japan. \\ ${ }^{*}$ Institute for Materials Research, Tohoku University, 2-1-1 Katahira, Aoba-ku, Sendai 980-8577, Japan. \\ ${ }_{43}$ President,Tohoku University, 2-1-1 Katahira, Aoba-ku, Sendai 980-8577, Japan.
}

Received August 22, 2007

\section{SYNOPSIS}

Hot pressing mechanisms are reviewed with special interest in the hot consolidation of metallic glass powders that exhibit a perfect viscous flow above the glass transition temperatures. The total densification process is divided into three stages; neck growth stage, cylindrical pore stage and isolated pore stage, for each of which the densification model and the critical relative density, separating the three stages, are unequivocally represented. The kinetic equations for the densification during hot pressing by the viscous flow mechanism are derived from those hitherto proposed for the power-law creep mechanism, in which the index of the constitutive equation is set to be unity. The equations for the relative density as functions of the hot pressing time and pressure are provided for the three stages of densification. An application of the kinetic equations to a processing design of the hot consolidation of metallic glass powders is demonstrated. The proposed set of the three equations enables an estimation of appropriate pressure and time for the full consolidation of metallic glass powders. The influence of entrapped gas in the final stage of hot pressing is also discussed.

\section{KEY WORDS}

metallic glass powders, viscous flow, hot pressing mechanisms, three stages of sintering, full densification

\section{1 はじめに}

バルク金属ガラスは過冷却液体形成能が大きく, 広い温度 範囲でガラス状態を維持するので, 通常のガラスと同様に成 形加工の自由度が大きい素材である. バルク金属ガラス自体 優れた材料特性を有しており，その加工成形能を活かして， 独特の材料機能を有する微小部品の開発が行われている ${ }^{1,2)}$. 一方, 金属ガラス球形粉はアトマイズ法により比較的効率よ く製造することができるので, 金属ガラスの粉末冶金は今後 大いに期待される分野である. 現状では金属ガラス粉の成形 固化は主としてガラス状態でのホットプレス, 型鍛造あるい はSPS成形によりなされている．過飽和液体の粘性や結晶化 挙動は温度に依存し, 高温になるほど, 粘性抵抗は小さくな り成形しやすくなるが結晶化するまでの時間も短くなる．し たがって，とりあえずはなるべく短時間で固化できる成形法 および成形条件が採用されているわけである.今後バルク金
属ガラスは医療機器や電子機器を含むさまざまな機械部品分 野へ応用されると考えられるが, その際成形加工条件をこれ まで以上に精密に制御する必要が生じてくるであろう. 本解 説では今後バルク金属ガラス材料の固化手法として主流にな ることが予想される粘性流動によるホットプレス固化につい て, そのメカニズム研究をレビューし, 本材料の開発に携る 研究者の利用しやすい形に整理したい.

$$
2 \text { ホットプレスメカニズム概観 }
$$

粉体の焼結過程は一般に, 初期におけるネック成長と粒子 中心間の接近, 中期の結晶粒エッジに存在する円筒状空隙の 収縮, および後期の結晶粒コーナーに存在する球形空隙の収 縮の 3 段階よりなる. ホットプレスにおいても，外部加圧に よる塑性変形やクリープ変形などによる密度上昇の寄与は大 きいとしても, 焼結組織の特徵としては上記 3 段階をへて緻 
密化が進行するとみてよい3).ホットプレスにおける粉体の 緻密化メカニズムについては, 粘性流動によるガラス球対の 合体を定式化した Frenkel ${ }^{4)}$ の理論に始まり, MacKenzie, Shuttleworth ${ }^{5)}$ の焼結体を多孔質粘性流体とみなした緻密化理 論や，焼結最終段階の組織を球殼モデルで近似し，べき乗ク リープ則に従って緻密化するとしたWolfe ${ }^{6}$ の理論, あるいは 拡散クリープを適用する試み”などがあり, 酸化物, 窒化物 系セラミックスの緻密化の解釈に供されている7).Kakar, Chaklader $^{8}$ は, 種々の充填構造をもつ球形粒子充填体につい て相対密度と粒子間接触部のサイズとの関係およびホットプ レス加圧力と粒子接触部にかかる垂直応力との関係を解析し, 塑性流動による相対密度と加圧力との関係式を導出している. 加圧過程における組織の3段階変化に対応した理論をはじめ

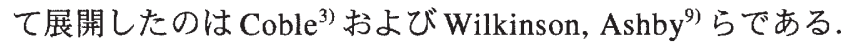
$\mathrm{Coble}^{33}$ は, ホットプレス緻密化の駆動力を考察し, 外力で促 進される体拡散による緻密化や Nabarro-Herring およびCoble 型拡散クリープによる緻密化を詳しく論じている.Wilkinson, Ashby ${ }^{91}$ はそれぞれの焼結段階に対してべき乗クリープ則によ る緻密化速度式を定式化し，そのリミットとして，粘性流動

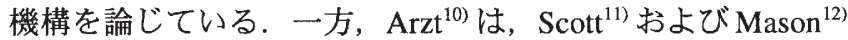
によりその構造が明らかにされたランダム最密充填体 (Random Dense Packing)について，圧密過程における粒子接 触部の数およびサイズの変化を解析し，それらを充填体相対 密度の関数として表した．また，加圧力と接触部応力との関 係 ${ }^{13)}$ を用いて, 塑性流動, 定常クリープ変形, 体拡散および 粒界桩散などの物質移動による絰密化速度式を導出した。 Arztの理論はそのリミティングケースとして無加圧焼結およ び室温金型成形をも包含しており，その後の修正も経て，現 在, 加圧焼結初期段階の理論的検討の基礎を成している. ホットプレス理論を検証するためには, 関係する粘性係数の ような物性值は既知として, 基本的には一定の加圧力に対す る, 被成形体の相対密度あるいはその変化速度と時間との関 係が必要になる. 円筒ホットプレス型のように加圧面の面積 が一定の場合には, 相対密度の変化はパンチの下降量から求 まる. Kaysserら ${ }^{14,15)}$ は, 後の 5 で説明するように, ホットプ レス初期過程における相対密度と成形圧の関係を球形単粒子 圧縮実験により求める方法を開発した. この方法は球形粒子 を用意できる場合は極めて便利な方法である.

なお, 通常のホットプレスにおいては，耐熱型が用いられ， 一軸成形により固化が行われるので, 一般的には原料粉と型 内壁之の摩擦の影響により高さ方向に成型圧分布の不均一が 生ずる.ここではダイス内壁の潤滑が十分であり，かつ成形 体の高さがその半径に比べて十分に小さいという条件で, 近 似的に等方的な圧力条件にあると仮定して話を進める.

\section{1 緻密化 3 段階の範囲}

\section{3 ホットプレスモデル}

緻密化の初期，中期および後期はそれぞれ相対密度でどの 範囲にあるのかということについては研究者によって異なる
が,ここでは十分な付加圧力下では $\mathrm{x} / \mathrm{R} \sim 0.5$ 程度まで焼結初 期段階の特徴が維持されるとして, 後で示す式 (5) より初期 と中期の境目を相対密度值 0.9 と仮定する. また, 2 面角が 180

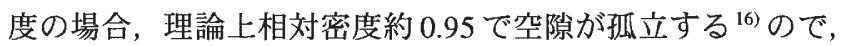
中期と後期の境目を 0.95 とする.

3.2 緻密化初期

$\mathrm{Arzt}^{10)}$ はランダム密充填に対する粒子配列の積算動径分布 関数 ${ }^{11,12)}$ を用いて, 緻密化に伴う組織の変化を, 組織因子と 相対密度Dの関係として表した. 等サイズの球形粒子のラン ダム最密充填体に抒ける充填密度は 0.64 , 平均配位数 ( 1 粒子 あたりの平均接触点数) は 7.3 である.ささら, 粒子半径方向 の配位数の変化いわゆる動径分布関数は次式のように表され る.

$$
\mathrm{Z}=\mathrm{Z}_{0}+\mathrm{C}\left(\mathrm{R} / \mathrm{R}_{0}-1\right)
$$

ここで, $\mathrm{Z}$ は半径方向の距離 $\mathrm{R}$ における配位数, $\mathrm{Z}_{0}=7.3, \mathrm{C}=$ $15.5, \mathrm{R}_{0}$ は初期粒子半径である.

$\mathrm{Arzt}^{10)}$ は, Fig.1に示したように, ランダム充填体をボロノ イセルで分割した. 充填体の緻密化過程はボロノイセルの収 縮と定義されるが,これは相対密度上はセル内における粒子 の膨張と等価である. Fig.2に示したように，セル内で粒子が 膨張すると, 最初から接触している箇所では物質の重複が起 こり,もともと離れていた籄所で新たな接触が生じる. Arzt ${ }^{10)}$ は重複した部分の体積を幾何学的に正確に計算し，それらを セル内の自由表面上に再配置した. 再配置のやり方には二通 りあり,ひとつは重複体積をセル内自由表面に均一に再堆積 させるやり方で, もうひとつは接触部付近の自由表面に焼結 ネックを形成するように堆積させるやり方である. 前者は塑 性変形が主たる流動メカニズムであるときの再配置形態 (変 形リミット)であり, 後者は付加荷重がゼロで表面張力のみ を駆動力とする無加圧焼結のケース(焼結リミット)である. 実際のホットプレスでは, 表面張力の駆動力も存在するゆえ

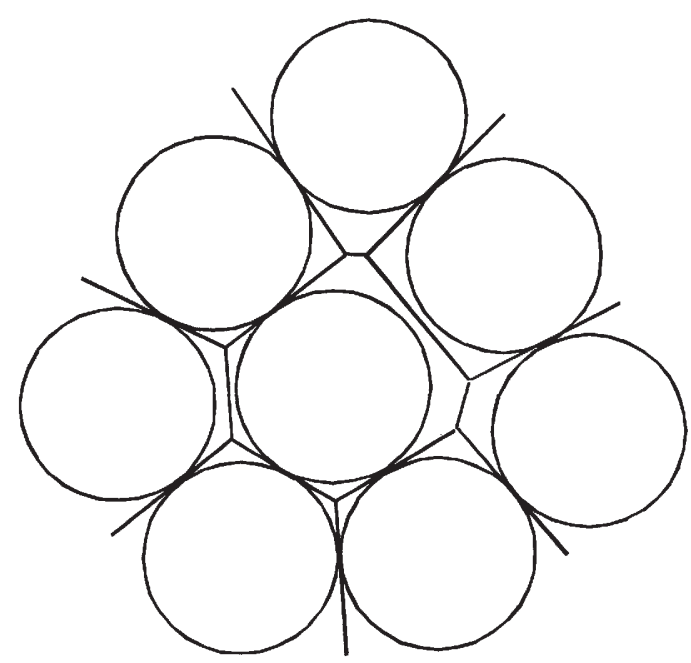

Fig.1 Volonoi cell depiction for the random dense packing of equal-sized spherical particles (According to Arzt ${ }^{10)}$ ). 


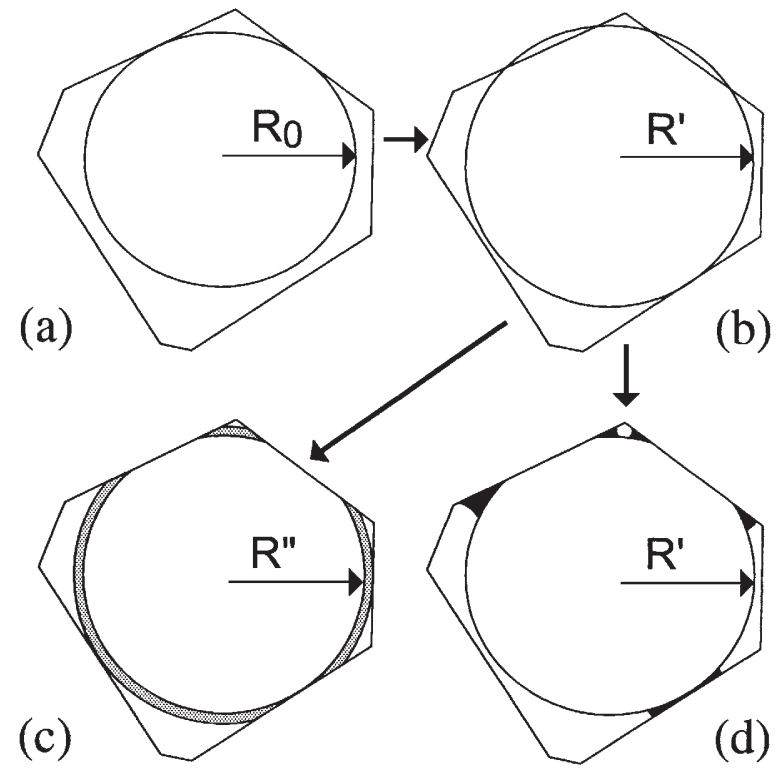

Fig.2 Densification during hot pressing is simulated by the shrinkage of the Volonoi cell, which is equivalent to the expansion of the particle in the cell. (a) Volonoi cell containing a single particle, (b) expansion of the particle yielding excess volume, (c) the excess volume is redistributed evenly on the free surface within the cell (compaction limit), (d) the excess volume is deposited at the contact peripheries (sintering limit) (According to Arzt ${ }^{10)}$ ).

に, 多かれ少なかれ両者の中間の堆積形態を示すことになる と考えられる. しかし, 十分な付加荷重の下で固化する場合 には, 変形は粒子全領域に亘ると考えられるので, これまで の報告では, 粒子半径の増加に関しては, 変形リミットを仮 定して論を進めている. 変形リミット条件を与える関係を次 式に示す ${ }^{10)}$.

$$
\mathrm{D} / \mathrm{D}_{0}=\left(\mathrm{R} / \mathrm{R}_{0}\right)^{1 / 3}
$$

ここで, $\mathrm{R}_{0}$ および $\mathrm{D}_{0}$ はそれぞれ初期粒子半径および初期充填 密度であり, Rおよび $\mathrm{D}$ は変形後の粒子半径および相対密度 である.ただし, このように変形の前後で球形を保存する条 件を設定する一方で, 接触部の周回の自由表面は局部的に安 定なネック形態をとると考える.

このような操作で得られる新しい粒半径に対して, $\mathrm{Arzt}^{10)}$ およびFischmeister, $\operatorname{Arzt}^{17)}$ は, 新しい接触点数, 接触面積, 接 触面半径 (ネックサイズ), ネック曲率半径などを相対密度の 関数として計算した. 彼らの式は実験解析に供するにはやや 煩雑すぎる憾みがある. Helle, Easterling, Ashby ${ }^{18)}$ は, ArztFischmeisterの式をよい近似で簡潔な式に整理している.以下 にそれらをまとめて示す19).

(a) 粒子 1 個あたりの接触点の数 Z:

$$
\mathrm{Z}=12 \mathrm{D}
$$

本式は, ランダム密充填体の初期密度 0.64 における初期接触

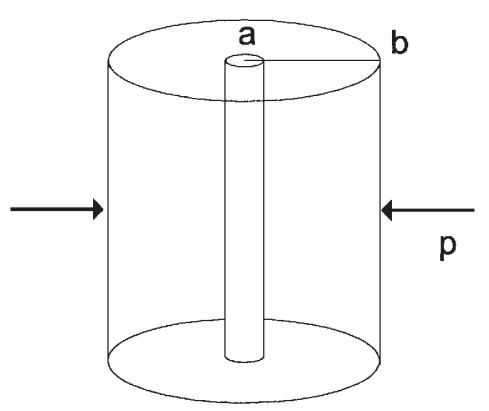

(a)

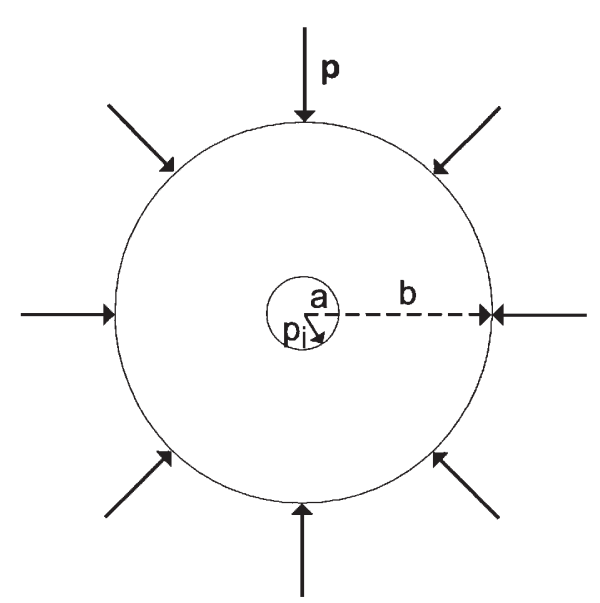

(b)

Fig.3 Densification models for the intermediate and final stage of hot pressing. (a) Intermediate stage: cylindrical shell model, (b) final stage: spherical shell model.

点数 (初期配位数) 7.3 を近似し, 完全緻密化時 $(\mathrm{D}=1)$ の接触 点数 12 を満たしている.

(b) 粒子接触面の平均面積 a:

$$
\mathrm{a}=(\pi / 3)\left(\mathrm{D}-\mathrm{D}_{0}\right) /\left(1-\mathrm{D}_{0}\right) \mathrm{R}_{0}^{2}
$$

(c) ネック半径 $\mathrm{x}$ :

$$
x=\sqrt{a / \pi}=\frac{1}{\sqrt{2}}\left(\frac{D-D_{0}}{1-D_{0}}\right)^{1 / 2} R_{0}
$$

(d) 粒子 1 個あたりの接触面積 aZ:

$$
\frac{\mathrm{aZ}}{4 \pi \mathrm{R}_{0}^{2}}=\frac{\mathrm{D}\left(\mathrm{D}-\mathrm{D}_{0}\right)}{1-\mathrm{D}_{0}}
$$

(e) 局部的な平衡にある粒子間ネックの曲率半径 $\rho$ :

$$
\rho=\frac{\mathrm{x}^{2}}{2\left(\mathrm{R}_{0}-\mathrm{x}\right)} \approx \mathrm{R}_{0}\left(\mathrm{D}-\mathrm{D}_{0}\right)
$$

3.3 緻密化中期, 後期段階

緻密化の中期段階は円筒状空隙の収縮により特徴づけられ るが, この場合の緻密化モデルは, Fig.3-(a)に示すように, 結 晶粒サイズを外殼径, 空隙サイズを内款径とする無限長の円 
筒殼とするのが最もシンプルである9). 円筒内半径を $\mathrm{a}$, 外半 径を b とすれば相対密度は次式で与えられる.

$$
\mathrm{D}=1-(\mathrm{a} / \mathrm{b})^{2}
$$

緻密化の最終段階は孤立球形化した空隙の収縮で特徵づけら れる．この場合の緻密化モデルは, 外殼径および内殼径をそ れぞれ平均結晶粒サイズおよび平均空隙径とする球款モデル (Fig3-(b))で置き換えることができる ${ }^{6,9)}$. 相対密度は同様に次 式で与えられる。

$$
\mathrm{D}=1-(\mathrm{a} / \mathrm{b})^{3}
$$

\section{4 粘性流動による緻密化速度式}

\section{1 緻密化の駆動力}

ホットプレスの緻密化のための駆動力 (F) は外部から付加 されるいわゆる成形圧 (P) からの寄与と粒子間ネック部に作 用する表面張力からの寄与とから成る. また, 焼結最終段階 において空隙が孤立化して気体が閉じ込められるとそれによ る内圧が発生し，そのぶん駆動力は減殺する．これらをすべ て考慮した駆動力 $\left(\mathrm{P}_{\mathrm{t}}\right)$ を式 (10) に示す ${ }^{3,6}$.

$$
P_{t}=P_{e}+P_{s}-P_{1}
$$

ここで, $\mathrm{P}_{\mathrm{e}}$ は焼結初期においては粒子間接触部に集中的に作 用する圧力であり, 中期および後期段階においては成形圧 $\mathrm{P}$ そのものである， $\mathrm{P}_{\mathrm{s}}$ は表面張力により生じる力であり， $\mathrm{P}_{1}$ は 孤立空隙の内圧である. $\mathrm{P}_{1}$ は焼結最終段階以外ではゼロであ る.

球形粒子のランダム密充填体に外圧 $\mathrm{P}$ を付加したときに, 粒子間接触部にかかる力は Morelus ${ }^{13)}$ により $4 \pi \mathrm{R}^{2} \mathrm{P} / \mathrm{ZD}$ と与え られており，それを接触面積 a で割って圧力の形にしたもの が $\mathrm{P}_{\mathrm{e}}$ である.したがって, 初期段階における Peは式(6)を用 いて次式で与えられる ${ }^{10)}$.

$$
P_{e}=\frac{4 \pi R^{2}}{a Z D} P=\frac{\left(1-D_{0}\right)}{D^{2}\left(D-D_{0}\right)} P
$$

一方，表面張力による駆動力 $\mathrm{P}_{\mathrm{s}}$ は粒子間ネックに対しては, 次式のような標準的な表現を用いる ${ }^{10)}$.

$$
\mathrm{P}_{\mathrm{s}}=\gamma\left(\frac{1}{\rho}-\frac{1}{\mathrm{x}}\right), \rho=\frac{\mathrm{x}^{2}}{2\left(\mathrm{R}_{0}-\mathrm{x}\right)}
$$

ここで, $\gamma$ は表面張力である. 式(5)および(7)を用いて式(12) は,

$$
P_{s}=\frac{1}{R_{0}\left(D-D_{0}\right)^{1 / 2}}\left(\frac{1}{\left(D-D_{0}\right)^{1 / 2}}-\sqrt{3}\left(1-D_{0}\right)^{1 / 2}\right) \gamma
$$

と表される.最終段階における孤立空隙の内圧は, 空隙閉鎖 時の雾囲気圧と相対密度をそれぞれ $\mathrm{P}_{\mathrm{c}}$ および $\mathrm{D}_{\mathrm{c}}$ とすると, 次 式のように表される.

$$
P_{1}=P_{c} \frac{\left(1-D_{c}\right) D}{(1-D) D_{c}}
$$

緻密化の初期段階における駆動力は(11)と(13)の和で与えら れる. 一方, 中期段階は円筒状空隙の収縮であり, $\mathrm{P}_{\mathrm{s}}=\gamma / \mathrm{r}$, (r: 空隙半径 ) で, 付加圧力 $\mathrm{P}$ はそのまま作用すると考えられる ので, 駆動力は, $\mathrm{P}+\gamma / \mathrm{r}$, また, 孤立空隙の収縮が緻密化に つながる最終段階は, $\mathrm{P}_{\mathrm{s}}=2 \gamma / \mathrm{r}$ で空隙内圧 (14) も考慮して駆 動力は $\mathrm{P}+2 \gamma / \mathrm{r}-\mathrm{P}_{1}$ と表される.

4.2 緻密化速度式

\subsection{1 ひずみ速度と付加圧力の構成式 ${ }^{9)}$}

粘性流動による緻密化速度式は，定常クリープ則指数を 1 とおいた一つのリミッティングケースとして導かれる. 定常 クリープにおけるひずみ速度 $\mathrm{d} \varepsilon / \mathrm{dt}$ と付加応力 $\sigma$ との関係は,

$$
\mathrm{d} \varepsilon / \mathrm{dt}=\mathrm{A} \sigma^{\mathrm{n}}
$$

と表される. Aおよび $\mathrm{n}$ は物質に依存する定数である．粘性 流動に対しては $\mathrm{n}=1, \mathrm{~A}=1 /(3 \eta),(\eta$ : せん断粘性係数 $)$ と置い $\tau$,

$$
\frac{\mathrm{d} \varepsilon}{\mathrm{dt}}=\frac{1}{3 \eta} \sigma
$$

と表される.

\subsection{2 初期段階速度式}

定常クリープ則によって粒子が変形流動する状況を正確に 定量的にフォローするのは難しい. Arzt, Ashby, Easterling ら ${ }^{20)}$ は, 面積 $\pi \mathrm{x}^{2}$ の円形パンチにより粒子がクリープ変形すると 仮定し, 粒子接近速度, 粒子のクリープひずみ速度および接 触面サイズとの関係を次元解析により近似的に求めた. 粒子 接近速度と相対密度の増加速度との関係式は, 式 (2) を時間 で微分して粒子半径増加速度と粒子接近速度を等しいと置く ことにより得られる.

上記の手続きで得られる緻密化速度式は, 次式に示すよう に, 相対密度 $\mathrm{D}$, 接触面サイズ $\mathrm{a}$, 初期粒子半径 $\mathrm{R}_{0}$, クリープ 定数 $\mathrm{A}$, および接触面にかかる圧力 $\mathrm{P}_{\mathrm{t}}$ の関数として表される.

$$
\frac{\mathrm{dD}}{\mathrm{dt}}=5.3\left(\mathrm{D}^{2} \mathrm{D}_{0}\right)^{1 / 3} \frac{\mathrm{x}}{\mathrm{R}_{0}}\left(\frac{\mathrm{A}}{3^{\mathrm{n}}}\right) \mathrm{P}_{\mathrm{t}}^{\mathrm{n}}
$$

粘性流動に対しては, $\mathrm{n}=1, \mathrm{~A}=1 /(3 \eta)$ とし, $\mathrm{x}$ に式(5) を代入 して整理すると, 粘性流動機構による初期段階の緻密化速度 は次式のようなる。

$$
\frac{\mathrm{dD}}{\mathrm{dt}}=\frac{5.3}{9 \eta} \mathrm{D}_{0}^{1 / 3} \mathrm{D}^{2 / 3}\left(\mathrm{D}-\mathrm{D}_{0}\right)^{1 / 2} \mathrm{P}_{\mathrm{t}}
$$

\subsection{3 中期 ・ 後期段階速度式}

Wilkinson ら ${ }^{-9)}$ は，3-3で述べた球殼モデルにおける空隙の 収縮について, 密度表式(9), 定常クリープ則(15)を用いて応 力場の平衡方程式を解き, 緻密化速度式を導いた. 中期段階 の円筒状空隙に対しても, 数因子が若干変化するのみで次式 で与えられる。 


$$
\frac{\mathrm{dD}}{\mathrm{dt}}=2 \mathrm{~A} \frac{\mathrm{D}(1-\mathrm{D})}{\left[1-(1-\mathrm{D})^{1 / \mathrm{n}}\right]^{\mathrm{n}}}\left(\frac{2}{\mathrm{n}} \mathrm{P}_{\mathrm{t}}\right)^{\mathrm{n}}
$$

粘性流動に対しては，式(19)は次式のようになる.

$$
\frac{\mathrm{dD}}{\mathrm{dt}}=\frac{4}{3 \eta}(1-\mathrm{D}) \mathrm{P}_{\mathrm{t}}
$$

中期段階の開始時 $\left(\mathrm{t}=\mathrm{t}_{1-2}\right)$ における相対密度を $\mathrm{D}=\mathrm{D}_{1-2}$ として, 式(20)を積分すると,

$$
\mathrm{D}=1-\left(1-\mathrm{D}_{1-2}\right) \exp \left(-\frac{4}{3} \frac{\mathrm{P}_{\mathrm{t}}}{\eta}\left(\mathrm{t}-\mathrm{t}_{1-2}\right)\right)
$$

となり，相対密度と時間の関係式が得られる。

最終段階についてもすでに述べたようにWilkinsonら り，(21) と数因子が若干異なる式(22)が得られる.

$$
\mathrm{D}=1-\left(1-\mathrm{D}_{2-3}\right) \exp \left(-\frac{3}{4} \frac{\mathrm{P}_{\mathrm{t}}}{\eta}\left(\mathrm{t}-\mathrm{t}_{2-3}\right)\right)
$$

ただし, $\mathrm{D}_{2-3}$ は最終段階の開始時 $\left(\mathrm{t}=\mathrm{t}_{2-3}\right)$ における相対密度で ある.

\section{5 単粒子圧縮試験による緻密化の推定}

Kaysser-Aslan-Petzow ${ }^{14,15)}$ は, Fig.4に示したような互いに平 行な平板ではさまれて圧縮される半径Rの球形粒子の変形を 分析し，以下のような関係式を得た，ただし，平板で圧縮さ れて変形流動する物質は球粒子の自由表面に均一に再配置さ れると仮定している.

$$
\begin{aligned}
& R=\left\{\left[\frac{2}{3} R_{0}^{3}+\frac{1}{3}\left(R_{0}-h\right)^{3}\right] /\left(R_{0}-h\right)\right\}^{1 / 2} \\
& x=\left\{2\left[h+\left(R-R_{0}\right)\right] R-\left[h+\left(R-R_{0}\right)\right]^{2}\right\}^{1 / 2}
\end{aligned}
$$

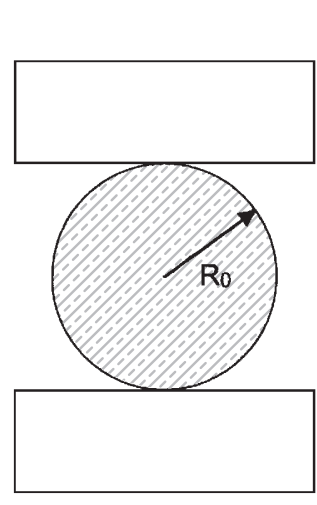

(a)

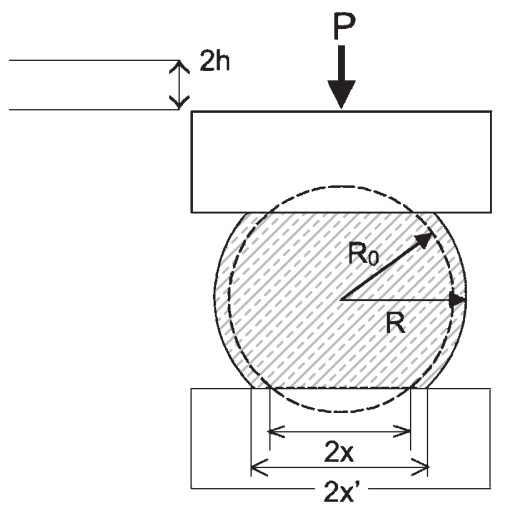

(b)
Fig.4 The single-particle compression test invented by Kaysser, Aslan and Petzow ${ }^{14,15)}$. The particle of radius $R_{0}$ is compressed by a pressure $\mathrm{P}$ to form a new radius $\mathrm{R}$.The vertical displacement, $h$, measured as a function of the pressing load is transformed into an equivalent densificationpressure relationship of the actual hot pressing.
ここで, $\mathrm{R}_{0}$ は初期粒子半径, $\mathrm{R}$ は変形中の粒子半径, $\mathrm{h}$ は Fig.4(b)に示した粒子の垂直方向変形量, $\mathrm{x}$ は平板と粒子間接触面 の半径である. 本単粒子圧縮実験における粒子変形は, 式(23) および(24)を $\mathrm{Arzt}^{9)}$ の解析に適用することにより, 次式で表 されるような等価ホットプレス密度 $\mathrm{D}_{\mathrm{eq}}$ に変換される.

$$
\mathrm{D}_{\mathrm{eq}}=\frac{\mathrm{D}_{0}}{1-\frac{1}{3}\left[0.3\left(7.3+8.6 \frac{\mathrm{x}^{2}}{\mathrm{R}_{0}^{2}}\right) \mathrm{h}^{2}\left(3 \mathrm{R}_{0}-\mathrm{h}\right)\right]}
$$

Kaysser ら ${ }^{15)}$ はさらに式(25)が次式のような簡潔な経験式で 表されることを見出している.

$$
\mathrm{D}_{\mathrm{eq}}=\mathrm{D}_{0}+2 \frac{\mathrm{h}}{\mathrm{R}_{0}}\left(1+\frac{\mathrm{h}}{\mathrm{R}_{0}}\right)
$$

一方, 単粒子圧縮における荷重 $\mathrm{P}_{\mathrm{sp}}$ とホットプレス荷重 $\mathrm{P}$ との 関係は,それぞれ粒子接触部にかかる圧力を等しいと置いて, 以下のように表される.

$$
\mathrm{P}=\frac{\mathrm{ZD}}{4 \pi \mathrm{R}_{0}^{3}} \mathrm{P}_{\mathrm{sp}}
$$

ただし， $\mathrm{P}_{\mathrm{sp}}$ は単粒子圧縮における付加荷重である. 他の記号 の意味はこれまで述べた通りである. Kaysserら ${ }^{15)}$ は, 合金鋼 粒子および銅粒子について, 単粒子実験とホットプレス実験 がよく一致することを実証している.

\section{6 バルク金属ガラス粉のホットプレス固化試算}

4.2.1, 2で示したホットプレス緻密化速度式を $\mathrm{P}_{\mathrm{e}}>\mathrm{P}_{\mathrm{s}}, \mathrm{P}_{1}, \mathrm{D}_{0}$ $=0.64, \mathrm{D}_{1-2}=0,90, \mathrm{D}_{2-3}=0,95$ として書き直すと, 初期段階に 対する式(18)は次式のように表される.

$$
\frac{\mathrm{dD}}{\mathrm{dt}}=\frac{0.183}{\mathrm{D}^{4 / 3}(\mathrm{D}-0.64)^{1 / 2}} \frac{\mathrm{P}}{\eta}
$$

なお，本式はそのままでは積分出来ないが，級数展開を利用 して近似的に積分形を求めることができる*1). 一方, 中期お よび後期段階に対する式(21)および(22)は, それぞれ以下の (29) および (30) となる.

$$
\begin{aligned}
& \mathrm{D}=1-(1-0.90) \exp \left(-\frac{4}{3} \frac{\mathrm{P}}{\eta}\left(\mathrm{t}-\mathrm{t}_{1-2}\right)\right) \\
& \mathrm{D}=1-(1-0.95) \exp \left(-\frac{3}{4} \frac{\mathrm{P}}{\eta}\left(\mathrm{t}-\mathrm{t}_{2-3}\right)\right)
\end{aligned}
$$

$\mathrm{t}_{1-2}$ および $\mathrm{t}_{2-3}$ は，式(28)および(29)においてそれぞれ相対密 度值 0.90 および 0.95 を与える時間として求められる.

粘性係数を $\eta=10^{10} \mathrm{~Pa} ・ \mathrm{~s}$ (たとえば $\mathrm{Pd}_{48} \mathrm{Ni}_{32} \mathrm{P}_{20}$ 合金の $853 \mathrm{~K}$ における值, $\left(\right.$ Kato $\left.{ }^{21)}\right)$ ) とし, ホットプレス圧力 10-100 MPa の範囲での相対密度と時間との関係をFig.5に示す. 各段階の

\footnotetext{
*1) 式(28)は, 複雑な数学関数を用いることにより $\mathrm{t}=\int 5.47537(\eta / \mathrm{P}) \mathrm{D}^{3 / 4}(\mathrm{D}-0.64)^{1 / 2} \mathrm{dD}$ の形に直して数値積分することができる。より簡明には被積分関数中の $\mathrm{D}^{4 / 3}(\mathrm{D}-0.64)^{1 / 2}$ ⿸ $\mathrm{D}=0.64$ の周りに6次の項まで展開して得られる多項式を 積分すると，ほぼ同程度の精度で $\mathrm{t}$ とDの関係を計算できる.
} 


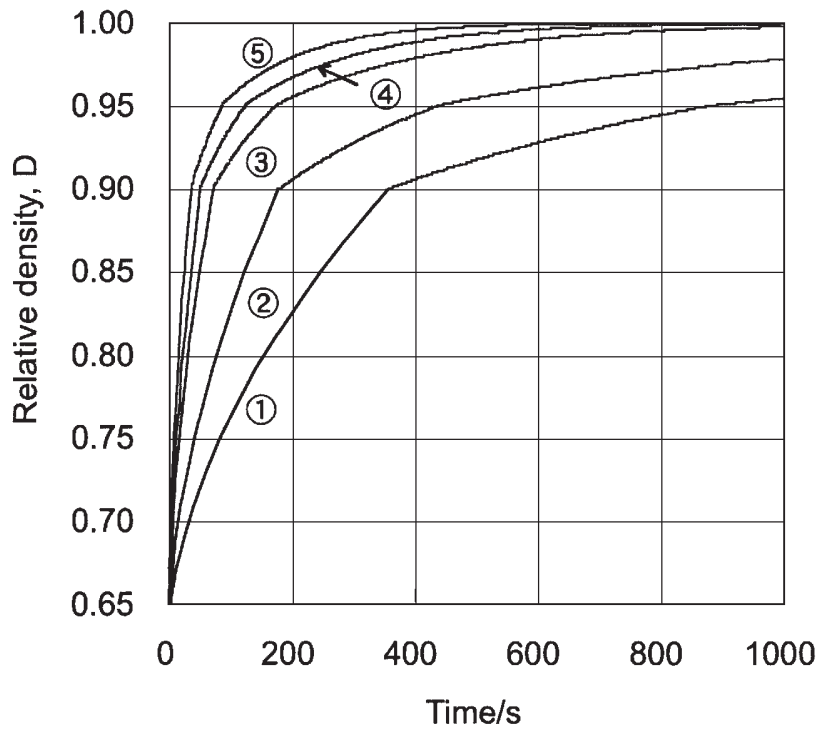

Fig.5 Relations between relative density and hot pressing time as predicted by the eqs. (25), (26) and (27) for the three stages of densification. Hot pressing pressure in MPa: (1) 10 , (2) 20 , (3) 50 , (4) 70 , (5) 100 .

境目で曲線にクニックがみられるが, 比較的よく連結した曲 線が得られていることがわかる.この条件で成形圧 $50 \mathrm{MPa}$ 上では, 1000秒以内にほぼ100\%緻密化する. Fig.6は, 初期, 中期および後期段階の終了時間を成形圧に対してプロットし たものである.ただし，後期段階については相対密度 $0.999 に$ 到垟する時間をこの場合の終了時間とした. 三つの段階を比 較してみると, 後期段階で成形圧に対する依存性が最も大き く,ほぼ完全に緻密化するためには十分に大きい成形圧が必 要であることがわかる. 例えば, 1000 秒以内に $99.9 \%$ 緻密化 するためには $60 \sim 70 \mathrm{MPa}$ 以上の付加圧が必要であることを 本図は示している.

\section{7 空隙内圧による緻密化の停止}

空隙が孤立化すると雾囲気ガスがその内部にトラップされ る.ガスを内包した孤立空隙の内圧は体積収縮に伴い上昇す る. いま, 表面張力による圧力は付加圧力に比べて小さいと して無視すると, 空隙内圧が付加圧力に等しくなれば駆動力 はゼロになるので緻密化は停止すると考えられる.すなわち， この場合の緻密化停止の条件はP $-\mathrm{P}_{1}=0$ であり,これは式(14) を用いて次式のように表される.

$$
D_{f}=\frac{P D_{c}}{P D_{c}+P_{c}\left(1-D_{c}\right)}
$$

ただし， $\mathrm{D}_{\mathrm{f}}$ は到達限界密度である，6にあげた金属ガラスの 固化例では, 1 気圧 $(\sim 0.1 \mathrm{MPa})$ の雾囲気ガス圧下でホットプ レスしたとすれば, $\mathrm{D}_{\mathrm{c}}=\mathrm{D}_{2-3}=0.95$ として, $60 \sim 70 \mathrm{MPa}$ の付 加圧で限界密度は $99.99 \%$ 以上になり，Fig.5に示した緻密化 曲線に対するガストラップの影響はきわめて小さい. 金属ガ

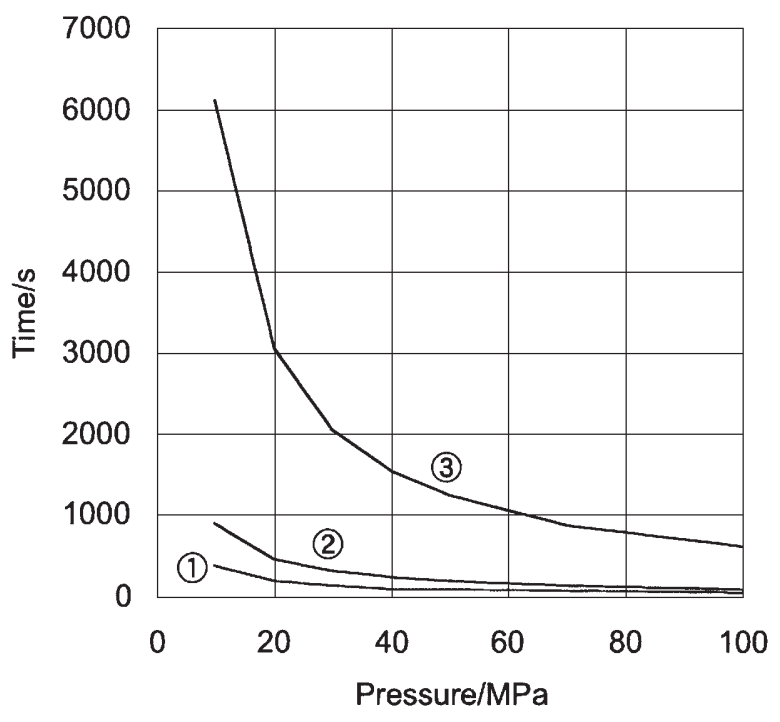

Fig.6 Time required to reach the ultimate relative densitiy of each densification stage. (1): Initial stage, $D_{1-2}=0.9$, (2): Intermediate stage, $D_{2-3}=0.95$, (3) : Final stage, $D=0.999$.

ラスのホットプレス固化は通常減圧下で行われるが, 本試算 の条件に限机ば不活性ガスや還元性の保護ガス中でも可とい うことになる.

\section{8 おわりに}

これまでのホットプレスおよびHIPについての緻密化理論 から, 粘性流動機構に関する部分を抽出し, 付加荷重, 相対 密度, ホットプレス時間の 3 因子の関係として提示した. こ れらの関係は実験測定の上でもあるいはその成立を検証する 場合でも比較的容易に取り扱える. しかし, 金属ガラス粉は, 材料機能や応用目的に応じて, 膨大な数の合金系が開発され ている ${ }^{1,2)}$.すべての合金系とは云わないまでも, 今後相当多 数の金属ガラス合金系についてホットプレス固化条件を決定 する必要性が生じることが予想される. それと同時に試料粉 の調製やホットプレス実験等, 膨大な時間がかかることも懸 念される.したがって，なるべく効率のよい実験手法の考案 が必要であろう. その意味でKaysserら ${ }^{14,15}$ の単粒子圧縮試験 によるホットプレス圧力と相対密度の関係の推定は, 金属ガ ラスの固化成形の研究を促進するものとして期待される. 一 方, 理論式に従って金属ガラスの固化条件を推定したいある いは固化成形プロセスを設計したい場合には, 金属ガラス粉 の性状やガラス遷移などは既知として，まずは当該金属ガラ スの粘性係数值, できればその温度依存性もわかれば的を得 た設計指針を得ることができよう．また，金属ガラス粒子同 士の界面での接合状態は固化体の特性とくに機械的特性を左 右すると考えられる、粘性流動で固化した金属ガラス粒子は 互いに金属結合状態にあるのか, あるいは薄い酸化膜に隔て られ強固な結合にいたっていないのか，あるいはその中間状 態にあるのか等々, この問題を解決することは金属ガラスの 
本来の機能特性を発揮する上で避けられない.これらの課題 については現在著者らのグループで一部検討中である.

\section{文献}

1) A.Inoue: "Stabilization of Metallic Supercooled Liquid and Bulk Amorphous Alloys", Acta Mater., 48(2000)279-306.

2) A.Inoue: "Metallic Glass", (in Japanese), Kogyo Zairyo, 54 (1)(2006) 32-33.

3) R.L.Coble: "Diffusion Models for Hot Pressing with Surface Energy and Pressure Effects as Driving Forces", J. Appl. Phys., $41(1970) 4798-4807$.

4) J.Frenkel: "Viscous Flow of Crystalline Bodies under the Action of Surface Tension", J. Phys., USSR, 9(1945)385-391.

5) J.K.MacKenzie and R.Shuttleworth: "A Phenomenological Theory of Sintering", Proc. Phys. Soc., 62B(1949) 833-52.

6) R.A.Wolfe: "Theory of Hot Pressing for a Nonlinear Viscous Solid", Bull. Am. Ceram. Soc., 46(1967)469, Abstract of $69^{\text {th }}$ Annual Meeting, (Quoted by M.R.Notis in Ref.7).

7) M.R.Notis, R.H.Smoak and V.Krishnamachari: "Interpretation of Hot Pressing Kinetics by Densification Mapping Techniques", Proc. $4^{\text {th }}$ Internl. Symp. on Sintering and Related Phenomena, Mater. Sci. Res., vol. 10, G..C.Kuczynski, Ed., Plenum Press, New York, (1975)p.493-507.

8) A.Kakar and A.C.D.Chaklader: "Deformation Theory of HotPressing", J. Appl. Phys., 38(1967)3223-3230.

9) D.S.Wilkinson and M.F.Ashby: "Pressure Sintering by Power Law Creep", Acta Metall., 23(1975) 1277-1285.

10) E.Arzt: "The Influence of an Increasing Particle Coordination on the Densification of Spherical Powders", Acta Metall., 30 (1982) 1883-1890.
11) G..D.Scott: "Radial Distribution of the Random Close Packing of Equal Spheres", Nature, 194(1962)956-958.

12) G..Mason: "Radial Distribution Functions from Small Packing of Spheres", Nature, 217(1968) 733.

13) O.Molerus: "Theory of Yield of Cohesive Powders", Powder Technology, 12(1975)259-275.

14) M.Aslan, W.A.Kaysser and G.Petzow: "Deformation of Spheres under Non-Constrained Conditions and during HIPing", Proc. of Internl. Conf. on HIP, Theory and Applications, Lulea, (1987)51-55.

15) W.A.Kaysser, M.Aslan, E.Arzt, M.Mitkov and G.Petzow: "Microstructural Development and Densification During Hipping of Ceramics and Metals", Powder Metallugy, 31(1988) 63-69.

16) W.Beere: "The Second Stage Sintering Kinetics of Powder Compaction", Acta Metall., 23(1975) 139.

17) H.F.Fischmeister and E.Arzt: "Densification of Powders by Particle Deformation", Powder Metallurgy, 26(1983)82-88.

18) A.S.Helle, K.E.Easterling and M.F.Ashby: "Hot-Isostatic Pressing Digrams: New Developments", Acta Metall., 33 (1985) 2163-2174.

19) R.Watanabe: "Densification Mechanism of Hot Isostatic Pressing", Bull. Japan Inst. of Metals, 28(1989)893-896.

20) E.Arzt, M.F.Ashby and K.E.Easterling: "Practical Applications of Hot-Isostatic Pressing Diagrams: Four Case Studies", Metallurgical Trans. A, 14A(1983)211-221.

21) H.Kato, T.Wada, M.Hasegawa, A.Inoue, J.Saida and H.S.Chen: "Fragility and Thermal Stability of Pt-and Pd-Based Bulk Glass Forming Liquids and Their Correlation with Deformability", Scripta Mater., 54(2000)2023-2027. 